\title{
HUBUNGAN PENGETAHUAN, SIKAP, DAN TINDAKAN IBU DENGAN STATUS GIZI ANAK BALITA DI KELURAHAN SEI KERA HILIR II KECAMATAN MEDAN PERJUANGAN
}

\author{
Tri Wulandari ${ }^{1}$, Mira Tiara Arizona ${ }^{2}$, Rinaldo Tambun ${ }^{3}$, Abdul Wahab $^{4}$ \\ 1,2,3 Mahasiswa Sarjana Kesehatan Masyarakat UNPRI \\ ${ }^{4}$ Dosen Sarjana Kesehatan Masyarakat UNPRI \\ Triwulandari1411@gmail.com
}

DOI : https://doi.org/10.35451/jkk.v2i1.233

\begin{abstract}
From the result of Riskesdas in 2018, it was found that the proportion of malnutrition and nutritional deficiency of balita in Indonesia was $17.7 \%$, consisted of $3.9 \%$ of them were malnutrition and $13.8 \%$ of them were nutritional deficiency. There were 5 children who suffered from nutritional deficiency and one child from malnutrition at Kelurahan Sei Kera Hilir II, Medan Perjuangan Sub-district. The research used analytic survey method and cross sectional design. The population was 164 women who had balita (under five year-old children) listed in posyandu of Kelurahan Sei Kera Hilir II, and 62 of them were used as the samples, taken by using Slovin formula. The data were analyzed by using chi square test. The result of the research showed that the respondents' knowledge was at $p$-value $=0.039 \quad(p<0.05)$, the respondents' attitude was at $p$-value $=0.017(p<0.05)$, and the respondents ${ }^{\prime}$ action was at $p$-value $=0.045(p<0.05)$ which was indicated that there was the correlation of the three variables with nutritional status of balita. It is recommended that the women who had balita at Kelurahan Sei Kera Hilir II pay attention to their children's nutritional status by giving them food supplement according to their children's needs.
\end{abstract}

Keywords: Knowledge, Attitude, Action, Nutritional Status

\section{PENDAhUluAN}

Pengetahuan, sikap, dan tindakan adalah unsur perilaku yang bersifat tertutup dan terbuka. Pengetahuan dan sikap bersifat tertutup artinya respon terhadap stimulus belum dapat diamati secara langsung, sedangkan tindakan bersifat terbuka maknanya respon terhadap stimulus sudah dapat dimati langsung karena berupa tindakan nyata. Ketiganya, Pengetahuan, sikap, dan tindakan sudah dapat diukur, sehingga perilaku dapat dianalisis.

Berbagai penelitian menunjukkan perilaku ibu dalam bentuk pengetahuan masih kurang, sebagaimana ditemukan Hayati (2011) di Serdang Bedagai pengetahuan kurang dalam pemberian makanan pada balita yaitu 33,3\%, Fadila, dkk (2017) di Desa Yosowilangun Lor Kabupaten Lumajang ibu memiliki pengetahuan kurang tentang gizi seimbang sebanyak 39,7\%, dan Susanti, dkk (2014) di Pekanbaru memiliki pengetahuan tentang gizi yang kurang yaitu $63,3 \%$.

Hasil penelitian yang dilakukan oleh Rahmatillah (2018), di Kabupaten Wonokusumo, Kecamatan Semampir Kota Surabaya, menunjukan hasil uji statistik hubungan pengetahuan terhadap status gizi balita adalah 
terdapat hubungan yang signifikan dengan $p=0,001(p<0,05)$ sehingga dapat disimpulkan bahwa terdapat hubungan antara pengetahuan dengan status gizi balita.

Selain pengetahuan ibu yang masih kurang, beberapa penelitian menunjukkan pula sikap ibu yang kurang. Hasil penelitian Harahap (2014) di Tapanuli Selatan menemukan $61 \%$ sikap ibu kurang dalam kejadian Bawah Garis Merah pada anak balita, Rahkmawati (2013) di Semarang memiliki sikap kurang $76,9 \%$ dalam pemberian makanan anak usia 12-24 bulan, dan Hayati (2011) di Serdang Bedagai 28\% ibu memiliki sikap kurang dalam pemberian makanan pada balita. Hasil penelitian ini yang dilakukan oleh Munthofiah (2008), di Kabupaten Sragen, Jawa Tengah, menyatakan adanya hubungan yang signifikan antara sikap ibu dengan status gizi anak balita. Sehingga dapat disimpulkan bahwa ada hubungan sikap ibu dengan status gizi balita $(p=0,000)$.

Di samping pengetahuan dan sikap ibu yang kurang, terbukti pula tindakan ibu masih kurang. Hasil penelitian Maulana, dkk (2012) di Pannampu terdapat $61 \%$ ibu memiliki tindakan kurang tentang gizi.

Hasil penelitian ini sejalan dengan hasil penelitian yang dilakukan oleh Rahmatillah (2018), di Kabupaten Wonokusumo, Kecamatan Semampir Kota Surabaya, menunjukan adanya hubungan tindakan terhadap status gizi anak balita yaitu terdapat hubungan yang bermakna dengan $p=0,001$ artinya terdapat hubungan antara tindakan dengan status gizi balita.

Pengetahuan, sikap, dan tindakan ibu yang masih kurang mengindikasikan perilaku ibu kurang. Penelitian Laraeni, dkk (2015) di Lombok mengungkapkan $57,6 \%$ ibu berperilaku kurang terhadap konsumsi energi. Demikian pula penelitian Rahkmawati (2013) di Semarang terdapat ibu yang berperilaku kurang $73,8 \%$ dalam pemberian makanan anak usia 12-24 bulan, serta Prakoso, dkk (2012) di Sumedang 56,8\% ibu yang berperilaku kurang dalam memenuhi gizi balita.

Berdasarkan hasil Riskesdas Tahun 2018 diketahui bahwa proporsi status gizi buruk dan gizi kurang pada balita di Indonesia sebesar $17,7 \%$ yang terdiri dari 3,9\% gizi buruk dan $13,8 \%$ gizi kurang. Proporsi terendah status gizi buruk dan gizi kurang pada tahun 2018 terdapat di provinsi Kepulauan Riau sebesar $13,0 \%$ dan proporsi tertinggi status gizi buruk dan gizi kurang pada tahun 2018 terdapat di provinsi Nusa Tenggara Timur sebesar 29,5\% (Kemenkes RI, 2018). Menurut Profil Kesehatan Sumatera Utara (2013) diketahui bahwa prevalensi anak balita gizi buruk dan kurang di Sumatera Utara pada Tahun 2013 sebesar $22,4 \%$ yang terdiri dari $8,3 \%$ gizi buruk dan $14,1 \%$ gizi kurang (Dinas Kesehatan Sumatera Utara, 2013).

Hasil survei pendahuluan bulan Agustus 2018 di Puskesmas Sentosa Baru tercatat jumlah anak balita sebanyak 5059 orang dan diperoleh data sebanyak 36 orang $(97,3 \%)$ anak balita gizi kurang dan 1 orang $(2,7 \%)$ berstatus gizi buruk. Sebagai salah satu kelurahan di wilayah kerja Puskesmas Sentosa Baru, Kelurahan Sei Kera Hilir II sengaja dipilih sebagai lokasi penelitian karena ditemukan 1 anak balita, berstatus gizi buruk dan 5 anak balita (2,6\%) berstatus gizi kurang dari 194 anak balita.

\section{METODE PENELITIAN}

Jenis penelitian yang dilakukan adalah survey analitik dengan rancangan cross sectional. yang bertujuan untuk mengetahui Hubungan pengetahuan, sikap, dan tindakan ibu dengan status gizi anak balita di Kelurahan Sei Kera Hilir II Kecamatan Medan Perjuangan .Penelitian dilaksanakan di Kelurahan Sei Kera Hilir II Kecamatan Medan Perjuangan. Adapun alasan dipilihnya penelitian ini karena pada kelurahan sei kera hilir II masih terdapat kasus anak balita yang mengalami status gizi kurang.Waktu penelitian dilakukan dari 
bulan September 2018 sampai dengan bulan Juli 2019. Pengumpulan data dilakukan pada tanggal 6 Maret sd 22 Maret 2019 dan penimbangan berat badan balita dilakukan pada tanggal 25 Maret sd 28 Maret 2019.Populasi penelitian adalah semua ibu yang memiliki anak balita dan terdaftar di Pos Yandu di Kelurahan Sei Kera Hilir II yaitu sebanyak 194 orang. Tetapi data yang valid hanya 164 dikarenakan pindah tempat tinggal, ibu yang memiliki anak kembar dan ibu memiliki 2 anak balita dalam 1 rumah. Sampel penelitian adalah sebagian ibu yang memiliki anak balita dan terdaftar di Pos Yandu di Kelurahan Sei Kera Hilir II. Besarnya sampel penelitian dihitung menggunakan rumus Solvin.

\section{Metode Analisis Data}

Adapun analisis data dalam penelitian ini adalah sebagai berikut

\section{Analisis Univariat}

Analisis univariatini bertujuan untuk mendeskripsikan karakteristik masing-masing variabel independen (pengetahuan, sikap dan tindakan ibu) dan variabel dependen (status gizi anak balita). Data tersebut ditampilkan dalam bentuk tabel distribusi frekuensi.

\section{Analisis Bivariat}

Analisis bivariatini bertujuan untuk mengetahui hubungan antara dua variabel yaitu variabel independent (pengetahuan, sikap dan tindakan ) dan variabel dependent (status gizi anak balita) dengan mengunakan uji chi-square. Uji statistik ini menggunakan taraf signifikan $p=0,05$. Dimana jikanilai ( $p$ $<0,05$ ) berarti $\mathrm{Ha}$ diterima dan $\mathrm{Ho}$ ditolak menunjukan bahwa terdapat hubungan antara variabel independen dan dependen.

\section{HASIL}

\section{Karakteristik Ibu}

\section{Umur}

Tabel 1. Distribusi Frekuensi Karakteristik Responden Berdasarkan Umur di Kelurahan Sei Kera Hilir II Kecamatan Medan Perjuangan

\begin{tabular}{ccc}
\hline Umur (tahun) & $\begin{array}{c}\text { Jumlah } \\
(\mathrm{n})\end{array}$ & $\begin{array}{c}\text { Persentase } \\
(\%)\end{array}$ \\
\hline $22-28$ & 19 & 30,6 \\
$29-35$ & 28 & 45,2 \\
$36-42$ & 11 & 17,7 \\
$43-49$ & 4 & 6,5 \\
\hline Total & 62 & 100,0 \\
\hline Dari & table $\quad 1$ & menunjukan
\end{tabular}

mayoritas umur responden 29-35 tahun sebanyak 28 orang $(45,2 \%)$ dan minoritas 43-49 tahun sebanyak 4 orang $(6,5 \%)$.

\section{Pendidikan}

Tabel 2. Distribusi Frekuensi Karakteristik Responden Berdasarkan Pendidikan di Kelurahan Sei Kera Hilir II Kecamatan Medan Perjuangan

\begin{tabular}{ccc}
\hline Pendidikan & $\begin{array}{c}\text { Jumlah } \\
(\mathrm{n})\end{array}$ & $\begin{array}{c}\text { Persentase } \\
(\%)\end{array}$ \\
\hline Tamat SD & & \\
Tamat SMP & 1 & 1,6 \\
Tamat SMA & 5 & 8,1 \\
TamatPerguruan & 50 & 80,6 \\
Tinggi & 6 & 9,7 \\
\hline Total & 62 & 100,0 \\
\hline Dari tabel & 2. & Karakteristik \\
responden berdasarkan pendidikan \\
relatif sudah baik karena mayoritas \\
responden tamat SMA sebanyak 50 \\
orang (80,6\%) dan minoritas tamatan \\
SD (Sekolah Dasar) sebanyak 1 orang \\
$(1,6 \%)$.
\end{tabular}

\section{Pekerjaan}

Tabel 3. Distribusi Frekuensi Karakteristik Responden Berdasarkan Pekerjaan di Kelurahan Sei Kera Hilir II Kecamatan Medan Perjuangan

\begin{tabular}{lcc}
\hline Pekerjaan & $\begin{array}{c}\text { Jumlah } \\
(\mathrm{n})\end{array}$ & $\begin{array}{c}\text { Persentas } \\
\mathrm{e}(\%)\end{array}$ \\
\hline PNS & 2 & 3,2 \\
Pegawai Swasta & 8 & 12,9 \\
$\begin{array}{c}\text { Wiraswasta/Pedagang } \\
\text { IRT }\end{array}$ & 14 & 22,6 \\
Total tabel 3, Karakteristik \\
\hline Dari tabe & 38 & 61,3 \\
\hline $\begin{array}{c}\text { responden berdasarkan pekerjaan, } \\
\text { mayoritas responden tidak bekerja }\end{array}$ \\
atau sebagai ibu rumah tangga \\
sebanyak 38 orang (61,3\%) dan \\
minoritas sebagai PNS (Pegawai \\
Negeri Sipil) sebanyak 2 orang \\
$(3,2 \%)$.
\end{tabular}




\section{Analisis Bivariat}

Tabel 8. Hubungan Pengetahuan Responden dengan Status Gizi Sampel di Kelurahan Sei Kera Hilir II Kecamatan Medan Perjuangan

\begin{tabular}{|c|c|c|c|c|c|c|c|c|c|c|c|}
\hline \multirow{3}{*}{$\begin{array}{l}\text { Pengetahuan } \\
\text { Responden }\end{array}$} & \multicolumn{8}{|c|}{ Status Gizi Sampel } & \multicolumn{2}{|c|}{ Total } & \multirow{2}{*}{$\begin{array}{c}P \\
\text { Value }\end{array}$} \\
\hline & \multicolumn{2}{|c|}{ Buruk } & \multicolumn{2}{|c|}{ Kurang } & \multicolumn{2}{|c|}{ Baik } & \multicolumn{2}{|c|}{ Lebih } & & & \\
\hline & $\mathrm{N}$ & $\%$ & $\mathrm{~N}$ & $\%$ & $\mathrm{~N}$ & $\%$ & $\mathrm{~N}$ & $\%$ & $\mathrm{~N}$ & $\%$ & \\
\hline Kurang & 1 & 3,3 & 8 & $\begin{array}{c}26 \\
7\end{array}$ & 20 & $\begin{array}{c}66 \\
7\end{array}$ & 1 & 3,3 & 30 & 100,0 & 0,039 \\
\hline Baik & 0 & 0,0 & 1 & 3,1 & 30 & $\begin{array}{c}93 \\
8\end{array}$ & 1 & 3,1 & 32 & 100,0 & \\
\hline
\end{tabular}

Berdasarkan Tabel 8, dapat diketahuiHubungan pengetahuan responden dengan status gizi sampel diperolehdari 32 sampel dengan pengetahuan responden baik, mayoritas mengalami status gizi baik yaitu sebanyak 30 orang $(93,8 \%)$ dan minoritas mengalami status gizi kurang dan lebih yaitu sebanyak 1 orang $(3,1 \%)$. Sebanyak 30 sampel dengan pengetahuan responden kurang baik, mayoritas mengalami status gizi baik yaitu sebanyak 20 orang $(66,7 \%)$ dan minoritas mengalami status gizi buruk dan lebih yaitu sebanyak 1 orang (3,3\%).

hubungan

Berdasarkan uji chi-square ada respondendengan status gizi sampel di Kelurahan Sei Kera Hilir II Kecamatan Medan Perjuangan dengan nilaip lebih kecil dari 0,05 yaitu $(p=0,039)$

Tabel 9. Hubungan Sikap Responden dengan Status Gizi Sampel di Kelurahan Sei Kera Hilir II Kecamatan Medan Perjuangan

\begin{tabular}{cccc}
\hline $\begin{array}{c}\text { Sikap } \\
\text { Responden }\end{array}$ & Status Gizi Sampel & Total & $\begin{array}{c}P \\
\text { Value }\end{array}$
\end{tabular}

\begin{tabular}{|c|c|c|c|c|c|c|c|c|c|c|c|}
\hline \multirow[b]{3}{*}{ Negatif } & \multicolumn{2}{|c|}{ Buruk } & \multicolumn{2}{|c|}{ Kurang } & \multicolumn{2}{|c|}{ Baik } & \multicolumn{2}{|c|}{ Lebih } & \multirow[b]{2}{*}{$\mathrm{N}$} & \multirow[b]{2}{*}{$\%$} & \\
\hline & $\mathrm{N}$ & $\%$ & $\mathrm{~N}$ & $\%$ & $\mathrm{~N}$ & $\%$ & $\mathrm{~N}$ & $\%$ & & & \\
\hline & 1 & 10,0 & 3 & $\begin{array}{c}30, \\
0\end{array}$ & 5 & $\begin{array}{c}50, \\
0\end{array}$ & 1 & $\begin{array}{c}10, \\
0\end{array}$ & 10 & 100,0 & 0,017 \\
\hline Positif & 0 & 0,0 & 6 & $\begin{array}{c}11, \\
5\end{array}$ & 45 & $\begin{array}{c}86 \\
5\end{array}$ & 1 & 2,0 & 52 & 100,0 & \\
\hline
\end{tabular}

Pada Tabel 9, dapat diketahui Hubungan sikap responden dengan status gizisampel dari 10 sampel dengan sikap responden negatif, mayoritas mengalami status gizi baik yaitu sebanyak 5 orang $(50,0 \%)$ dan minoritas mengalami status gizi buruk dan lebih yaitu sebanyak 1 orang $(10,0 \%)$. Sebanyak 52 sampel dengan sikap responden positif, mayoritas mengalami status gizi baik yaitu sebanyak 45 orang $(86,5 \%)$ dan minoritas mengalami status gizi lebih yaitu sebanyak 1 orang (2,0\%).

Berdasarkan uji chi-square ada ada hubungan antara sikap responden dengan status gizi sampel di Kelurahan Sei Kera Hilir II Kecamatan Medan Perjuangan dengan nilaip lebih kecil dari 0,05 yaitu $(p=0,017)$ 
Tabel 10. Hubungan Tindakan Responden dengan Status Gizi Sampel di Kelurahan Sei Kera Hilir II Kecamatan Medan Perjuangan

$\begin{array}{ccc}\begin{array}{c}\text { Tindakan } \\ \text { Responden }\end{array} & \text { Status Gizi Sampel } & \text { Total } \\ \text { Value }\end{array}$

\begin{tabular}{ccccccccccc} 
& \multicolumn{2}{c}{ Buruk } & \multicolumn{2}{c}{ Kurang } & \multicolumn{2}{c}{ Baik } & \multicolumn{2}{c}{ Lebih } \\
\cline { 2 - 11 } & $\mathrm{n}$ & $\%$ & $\mathrm{~N}$ & $\%$ & $\mathrm{~N}$ & $\%$ & $\mathrm{~N}$ & $\%$ & $\mathrm{~N}$ & $\%$ \\
\cline { 2 - 10 } $\begin{array}{c}\text { Kurang } \\
\text { Baik }\end{array}$ & 0,0 & 5 & 38, & 8 & 61, & 0 & 0,0 & 13 & 100,0 \\
Baik & 1 & 2,0 & 4 & 8,2 & 42 & 85, & 2 & 4,1 & 49 & 100,0
\end{tabular}

Pada Tabel 10, dapat diketahuiTindakan responden dengan status gizi sampel dari 13 sampel dengan tindakan responden tidak baik, mayoritas mengalami status gizi baik yaitu sebanyak 8 orang $(61,5 \%)$ dan minoritas mengalami status gizi kurang yaitu sebanyak 5 orang $(38,5 \%)$. Sebanyak 49 sampel dengan tindakan responden baik, mayoritas mengalami status gizi baik yaitu sebanyak 42 orang $(85,7 \%)$ dan minoritas mengalami status gizi buruk yaitu sebanyak 1 orang $(2,0 \%)$.

Berdasarkan uji chi-square ada hubunganantaratindakan responden dengan status gizi sampel di Kelurahan Sei Kera Hilir II Kecamatan Medan Perjuangan dengan nilaip lebih kecil dari 0,05 yaitu $(p=0,045)$.

\section{PEMBAHASAN}

\section{Hubungan Pengetahuan Ibu denganStatus Gizi Anak Balita Di Kelurahan Sei Kera Hilir II Kecamatan Medan Perjuangan}

Berdasarkan uji chi-square diperoleh hasilP value $=0,039$, dimana $P$ value $<0,05$ maka Ha diterima sehingga ada hubungan pengetahuan responden dengan status gizi sampel di Kelurahan Sei Kera Hilir II Kecamatan Medan Perjuangan.

$\mathrm{Hal}$ ini sejalan dengan hasil penelitian yang didapatkan oleh (Fadila dkk, 2017) tentang hubungan pengetahuan dan perilaku ibu tentang gizi seimbang dengan status gizi anak
TK di Desa Yosowilangun Lor Kabupaten Lumajang dengan hasil nilai $\mathrm{P}=0,000$ maka adanya hubungan pengetahuan responden dengan status gizi sampel.

Hasil penelitian menunjukkan bahwa 32 responden yang memiliki pengetahuan baik mayoritas mengalami status gizi baik yaitu sebanyak 30 orang $(93,8 \%)$ dan minoritas mengalami status gizi kurang yaitu sebanyak 1 orang $(3,3 \%)$. Dari 30 responden yang memiliki pengetahuan kurang mayoritas mengalami status gizi baik yaitu sebanyak 20 orang dan minoritas mengalami status gizi kurang yaitu sebanyak 1 orang $(3,1 \%)$. Hal tersebut diasumsikan bahwa responden dengan pengetahuan kurang tetapi status gizi baik dikarenakan masih adanya ibu dengan pendidikan SD dan SMP sehingga minimnya pengetahuan. Sebagian besar responden yaitu ibu rumah tangga sehingga kesulitan untuk mendapatkan informasi mengenai status gizi yang baik untuk anak balita, Karena minimnya sumber informasi untuk mereka yang hanya berkegiataan dirumah sebagai ibu rumah tangga. Sedangkan pengetahuan responden baik tetapi status gizinya kurang dikarenakan responden tidak memberikan tindakan yang tepat untuk memenuhi kebutuhan gizi pada anak balita.

\section{Hubungan Sikap Ibu Dengan Status Gizi Anak Balita Di}




\section{Kelurahan Sei Kera Hilir II} Kecamatan Medan Perjuangan

Berdasarkan uji chi-square diperoleh hasilP value $=0,017$, dimana $\mathrm{P}$ value $<0,05$ maka $\mathrm{Ha}$ diterima sehingga ada hubungan sikap responden dengan status gizi sampel di Kelurahan Sei Kera Hilir II Kecamatan Medan Perjuangan.

Hasil penelitian ini sejalan dengan hasil penelitian yang dilakukan oleh Munthofiah (2008), di Kabupaten Sragen, Jawa Tengah, adanya hubungan yang signifikan antara sikap ibu dengan status gizi anak balita $(p=0,000)$. Ibu yang mempunyai sikap yang baik mempunyai kemungkinan 5 kali lebih besar agar anak balitanya mempunyai status gizi yang baik dibandingkan ibu yang sikapnya buruk.

Hasil penelitian menunjukkan bahwa 52 responden yang memiliki sikap positif mayoritas mengalami status gizi baik yaitu sebanyak 45 orang $(86,5 \%)$ dan minoritas mengalami status gizi buruk sebanyak 1 orang $(10,0 \%)$. Dari 10 responden yang memiliki sikap negatif mayoritas mengalami status gizi baik yaitu sebanyak 5 orang $(50,0 \%)$ dan minoritas mengalami status gizi lebih yaitu sebanyak 1 orang $(2,0 \%)$. Hal tersebut diasumsikan bahwa sikap responden yang positif akan membawa dampak yang positif juga sehingga status gizi sampel normal dan responden yang memiliki sikap positif dengan status gizi kurang menunjukan bahwa responden sudah memiliki sikap yang positif tetapi dia belum mau untuk menunjukan sikap menerima, merespon, menghargai dan bertanggung jawab atas apa yang telah mereka ketahui. Sedangkan responden yang mempunyai sikap yang negatif status gizi sampel kurang dikarenakan sikap merupakan kesiapan untuk bereaksi terhadap objek dilingkungan tertentu sebagai suatu penghayatan terhadap objek (Notoadmotjo, 2007). Sehingga sikap ibu balita yang positif akan mempengaruhi perubahan perilaku yang positif juga.

\section{Hubungan Tindakan Ibu Dengan Status Gizi Anak Balita Di Kelurahan Sei Kera Hilir II Kecamatan Medan Perjuangan}

Berdasarkan uji chi-square diperoleh hasilP value $=0,045$, dimana $\mathrm{P}$ value $<0,05$ maka $\mathrm{Ha}$ diterima sehingga ada hubungan tindakan responden dengan status gizi sampel di Kelurahan Sei Kera Hilir II Kecamatan Medan Perjuangan.

Hasil penelitian ini sejalan dengan hasil penelitian yang dilakukan oleh Rahmatillah (2018), di Kabupaten Wonokusumo, Kecamatan Semampir Kota Surabaya, menunjukan hasil uji statistik hubungan tindakan terhadap status gizi balita adalah terdapat hubungan yang bermakna dengan $p=0,001$ artinya terdapat hubungan antara tindakan dengan status gizi balita.

Hasil penelitian ini sejalan dengan hasil penelitian yang dilakukan oleh Munthofiah (2008), di Kabupaten Sragen, Jawa Tengah, adanya hubungan yang signifikan antara tindakan ibu dengan status gizi anak balita $(p=0,001)$. Ibu yang perilakunya baik mempunyai kemungkinan 3 kali lebih besar untuk mempunyai balita dengan status gizi baik bila dibandingkan dengan ibu yang perilakunya buruk.

Hasil penelitian menunjukkan bahwa 49 responden yang memiliki tindakan baik mayoritas mengalami status gizi baik yaitu sebanyak 42 orang $(85,7 \%)$ dan minoritas mengalami status gizi buruk sebanyak 1 orang $(2,0 \%)$. Dari 13 responden yang memiliki tindakan kurang mayoritas mengalami status gizi baik yaitu sebanyak 8 orang $(61,5 \%)$ dan minoritas mengalami status gizi kurang sebanyak 5 orang $(38,5 \%)$. Hal tersebut diasumsikan bahwa suatu sikap tidak selalu terwujud dalam suatu tindakan hal ini sesuai dengan kenyataan bahwa sikap yang sudah positif terhadap nilai-nilai kesehatan tidak selalu terwujud dalam suatu tindakan nyata dan terbukti masih ada tindakan ibu yang masih sangat kurang dalam memperhatikan gizi balitanya. 


\section{KESIMPULAN}

Berdasarkan hasil penelitian tentang hubungan pengetahuan, sikap, dan tindakan ibu dengan status gizi anak balita di kelurahan sei kera hilir II kecamatan medan perjuangan dapat ditarik kesimpulan bahwa :

Ada hubungan pengetahuan ibu dengan status gizi pada anak balita di Kelurahan Sei Kera Hilir II Kecamatan Medan Perjuangan.Ada hubungan sikap ibu dengan status gizi pada anak balita di Kelurahan Sei Kera Hilir II Kecamatan Medan Perjuangan.Ada hubungan tindakan ibu dengan status gizi pada anak balita di Kelurahan Sei Kera Hilir II Kecamatan Medan Perjuangan.

\section{SARAN}

1. Bagi Responden

Dikarenakan masih kurangnya pengetahuan ibu di kelurahan sei kera hilir II. Disarankan kepada ibu-ibu di kelurahan sei kera hilir II agar diberi bekal pengetahuan di puskesmas dan pos yandu. Terutama mengenai status gizi balita seperti gizi seimbang.

2. Bagi Petugas

Untuk petugas kesehatan di Pos Yandu dan Puskesmas di kelurahan sei kera hilir II kecamatan medan perjuangan perlunya peningkatan penyuluhan kepada ibu-ibu yang mempunyai anak balita untuk menambah pengetahuan mengenai status gizi pada anak balita. Dan meningkatkan program yang sudah terlaksana dengan mengevaluasi program penanganan kasus gizi secara berkala, sehingga dapat memastikan telah terlaksana sesuai kegiatan dan sasaran.

\section{DAFTAR PUSTAKA}

Fadila, Rista Nur. (2017) HUBUNGAN PENGETAHUAN DAN PERILAKU IBU TENTANG GIZI SEIMBANG DENGAN STATUS GIZI ANAK TK DI DESA YOSOWILANGAN LOR
KABUPATEN LUMAJANG. Jurnal Penelitian.

Hayati, Maria Posma. (2011). PENGARUH PENGETAHUAN DAN SIKAP IBU SERTA DUKUNGAN TENAGA KESEHATAN TERHADAP PEMBERIAN MAKANAN PADA BALITA DI PUSKESMAS BANDAR KHALIFAH KABUPATEN SERDANG BEDAGAi. Tesis FKM USU.

Kemenkes RI .(2010). Standar Antropometri Penilaian Status Gizi Anak. Jakarta : Kemenkes RI.

Kemenkes RI .(2018). Riset Kesehatan Dasar Tahun 2018. http://www.depkes.go.id/resou rces/download/infoterkini/mate ri rakorpop 2018/Hasil\%20Ris kesdas\%202018.pdf. Diakses 13 Desember 2018

Laraeni, Yuli, dkk. (2015). HUBUNGAN TINGKAT PENGETAHUAN, SIKAP, DAN PERILAKU IBU TERHADAP KONSUMSI ZAT GIZI (ENERGI,PROTEIN) PADA BALITA GIZI KURANG DI DESA LABUHAN LOMBOK.

Maulana, Malik, dkk. (2012). GAMBARAN PENGETAHUAN, SIKAP, DAN TINDAKAN TERHADAP STATUS GIZI SISWA SD INPRES 2 PANNAMPU. Jurnal Penelitian.

Munthofiah. Siti. (2008). HUBUNGAN ANTARA PENGETAHUAN, SIKAP,DAN PERILAKU IBU DENGAN STATUS GIZI ANAK BALITA DI KABUPATEN SRAGEN, JAWA TENGAH. JURNAL PENELITIAN. Diakses 10 April 2019

Notoatmodjo, S. (2007). Promosi Kesehatan dan Ilmu Perilaku. Jakarta : Rineka Cipta.

Profil Kesehatan Sumatera Utara (2013). Status Gizi Masyarakat. http://www.depkes.go.id/resou rces/download/profil/PROFIL K ES PROVINSI 2013/02 Prov S umut 2013.pdf. Diakses 20 Oktober 2018

Puskesmas Sentosa Baru. (2018). Profil Puskesmas Sentosa Baru 
Received: 05 September 2019 :: Accepted: 14 September 2019:: Publish: 31 Oktober 2019

Tahun 2018. Medan :

Puskesmas Sentosa Baru.

Prakoso, Indra Bakti, Ahmad Yamin dan Raini Diah Susanti. (2012). HUBUNGAN PERILAKU IBU DALAM MEMENUHI KEBUTUHAN GIZI DAN TINGKAT KONSUMSI ENERGI DENGAN STATUS GIZI BALITA DI DESA CIBEUSI KECAMATAN JATINANGGOR KABUPATEN SUMEDANG. http://journal.unpad.ac.id/ejour nal/article/view/761. Jurnal penelitian

Rakhmawati, Nuris Zuraida. (2013). HUBUNGAN PENGETAHUAN DAN SIKAP IBU DENGAN PERILAKU DALAM PEMBERIAN MAKANAN ANAK USIA 12-24 BULAN DI SEMARANG. http://eprints.undip.ac.id/4200 2/1/581 NURIS ZURAIDA RAK HMAWATI G2C009005.pdf. Diakses 27 Oktober 2018

Rahmatillah, Daning Kurnia. (2018). HUBUNGAN PENGETAHUAN SIKAP DENGANNOTOATMODJO, S. (2007 TINDAKAN TERHADAP STATUS GIZI DI KELURAHAN WONOKUSUMO KECAMATAN SEMAMPIR KOTA SURABAYA. http://ejournal.unair.ac.id

Susanti, Rika, Ganis Indriati, Wasisto Utomo. (2014). HUBUNGAN PENGETAHUAN IBU TENTANG GIZI DENGAN STATUS GIZI ANAK USIA 1-3 TAHUN DI WILAYAH KERJA PUSKESMAS REJOSARI KELURAHAN SAIL KECAMATAN TENAYAN RAYA KOTA PEKANBARU. https://media.neliti.com/media Lpublications/187452-IDhubungan-pengetahuan-ibutentang-gizi-de.pdf. Jurnal penelitian. 